UDC 316.422.44

JEL: H81, N90, 038, R53

https://doi.org/10.33619/2414-2948/48/29

\title{
FEATURES OF THE SUPPORT OF THE INNOVATIVE ACTIVITY: FOREIGN EXPERIENCE AND PRACTICE FOR UZBEKISTAN
}

CKurpayanidi K., ORCID: 0000-0001-8354-1512, SPIN-code: 2321-7606, ResearcherID: Q-55962016,Ph.D., Fergana Polytechnic Institute,Fergana,Uzbekistan,w7777@mail.ru CMamurov D., Fergana Polytechnic Institute, Fergana, Uzbekistan, g7777@mail.ru

\section{ОСОБЕННОСТИ ПОДДЕРЖКИ ИННОВАЦИОННОЙ ДЕЯТЕЛЬНОСТИ: ЗАРУБЕЖНЫЙ ОПЫТ И ПРАКТИКА ДЛЯ УЗБЕКИСТАНА}

СКурпаяниди К. И., ORCID: 0000-0001-8354-1512, SPIN-код: 2321-7606, ResearcherID: Q-5596-2016, Ph.D., Ферганский политехнический институт,

2. Фергана, Узбекистан,w7777@mail.ru

СМамуров Д. Э., Ферганский политехнический институт, 2. Фергана, Узбекистан, g7777@mail.ru

Abstract. In modern conditions, an important condition for the dynamic development of the Republic of Uzbekistan is the accelerated implementation of the modern innovative technologies in the economy, social and other spheres with widespread use of science and technology. Dynamically developing all spheres of public and state life of the country require close follow-up of ongoing reforms on the basis of modern innovative ideas, developments and technologies that ensure a fast and high-quality breakthrough of the country into the ranks of the world civilization leaders. This determines the relevance of the topic being developed. The paper studies various approaches to the methodology of state support of innovation in economically developed and dynamically developing countries of the world. Based on this analysis, taking into account the characteristics of the national economy, the authors proposed areas of state support for the innovation process in the Republic of Uzbekistan.

Аннотащия. В современных условиях важным условием динамичного развития Республики Узбекистан является ускоренное внедрение современных инновационных технологий в отрасли экономики, социальную и иные сферы с широким применением достижений науки и техники. Динамично развивающиеся все сферы общественной и государственной жизни страны требуют тесного сопровождения проводимых реформ на основе современных инновационных идей, разработок и технологий, обеспечивающих быстрый и качественный рывок страны в ряды лидеров мировой цивилизации. Это обуславливает актуальность разрабатываемой темы. В работе изучаются различные подходы к методике государственной поддержки инновационной деятельности в экономически развитых и динамично развивающихся странах мира. На основе данного анализа с учетом особенностей национальной экономики авторами предложены направления государственной поддержки инновационного процесса в Республике Узбекистан.

Keywords: innovation, innovative process, innovative developments, state regulation, state programs, small innovative enterprises, RADW.

Ключевые слова: инновация, инновационный процесс, инновационные разработки, государственное регулирование, государственные программы, малые инновационные предприятия, НИОКР. 


\section{Introduction}

At present, it is quite obvious that different states demonstrate different levels of the innovative development, but sometimes they can be similar to each other in terms of models, institutions, mechanisms of this development, the subject-object and subject side of innovation [1]. Thus, the relevance of the study of this problems we have stated is increasing due to the presence of a large number of countries for analyzing the prerequisites, factors and conditions for the implementation of innovation policy. An important condition for the dynamic development of the Republic of Uzbekistan is the accelerated introduction of modern innovative technologies in the economy, social and other areas with widespread use of the achievements of science and technology $[2,3]$.

The rapidly developing all spheres of public and state life of the country requires close follow-up of ongoing reforms on the basis of modern innovative ideas, developments and technologies that ensure a fast and high-quality breakthrough of the country into the ranks of world civilization leaders.

The key source of the country's competitive advantage in the world arena today is innovation. The problem of creating an innovative environment, that is, an environment in which the process of sharing knowledge and technologies among individuals, enterprises and institutes opens up the possibility of transforming new ideas into commercially successful products and services, is not only actively researched by scientists around the world, but also reflected in the development strategies of the various states as a key factor in competitiveness: at the moment, the concept of an innovative environment is used in such countries as the USA, Japan, Israel, Brazil, India, China, Russia and many developing countries [1].

Undoubtedly, the key to the successful transformation of the state economy is the ability to track the results of the interaction of the elements of a developing innovative environment, to analyze the experience gained in order to make timely adjustments. Such monitoring requires a universal mechanism for evaluating the measures taken by the state, which, according to the results of the analysis, allows directing national funds in support of only those innovative initiatives that can bring the country's economy to a new level of competitiveness. Currently, the problem of forming a national innovation environment is a strategic priority for the development of the Republic of Uzbekistan.

\section{Research methodology}

The article used high-quality analytical methods, expert assessment methods, scientific review, abstract-logical thinking, comparative analysis, as well as methods of induction and deduction. The study used statistical data from the Ministry of Economy and Industry of the Republic of Uzbekistan, the State Committee on Statistics of the Republic of Uzbekistan. The paper used secondary sources of information.

\section{Analysis and results}

In many developed and dynamically developing countries, various methods of state stimulation of the innovative activity in the sector of small private business (SPB) are used. Here are a number of state programs for financing and technical support of innovative developments of the SPB in the direction of government organizations. In addition, there are many regulatory, financial, fiscal and property levers at the state and regional levels that contribute to the development of the innovation in all areas of business. Our analysis showed that the following typical forms of stimulating the innovative activity of small businesses have been formed in world practice: 
- Providing credit resources, including without interest payments (Sweden); gratuitous loans to cover $50 \%$ of the costs of innovation (Germany) [4];

- Direct financing, which reaches $50 \%$ of the cost of creating new products and technologies (France, USA and others);

- Reducing state fees for individual inventors and providing them with fiscal benefits (Austria, Germany, USA, Japan, etc.), as well as creating special infrastructure for their support and economic insurance (Japan) [5,6];

- State targeted programs of the financial and technical support for innovative public-private partnerships that carry out RADW on the topics of government organizations (USA, Japan, Great Britain, India, China, etc.) [7];

- Targeted RADW subsidies (in all economically developed countries);

- Creation of a wide system of the venture capital funds used for implementing innovative projects by small businesses (all economically developed and dynamically developing countries);

- Organization of innovation implementation funds taking into account possible commercial risk (England, Germany, France, Switzerland) [8];

- Regulatory support for the protection of the intellectual property and copyrights (in all developed countries);

- Deferral or exemption of duties if the invention relates to energy saving (Austria);

- Free services of patent attorneys at the request of individual inventors, exemption from payment of duties (Netherlands, Germany, Japan, India);

- Tax relief for enterprises operating in the innovation sphere, including exemption from taxation of RADW expenses, preferential taxation of educational institutions and research institutes (USA, Great Britain, India, China, Japan);

- Government programs to reduce risks and reimburse risk losses (USA, Japan);

- Establishment of a network of science parks, business incubators and zones of technological development (in all developed and developing countries);

- Formation of powerful state organizations (corporations, agencies) that provide comprehensive scientific, technical, financial and industrial support for innovative small enterprises (USA, China, India, India;

- Information-specific specialized sites for advanced technologies and innovative developments, enabling interested enterprises to quickly find the necessary technical solutions and partnerships.

In our view, the powerful factor of the stimulating economic and innovative developing of the many developed countries were formation of the clusters, including the most efficient and connected enterprises of the various sizes, leading group companies the first places and provide the competitive place on the sectorial, national and the world markets. The cluster approach has become actively used to formulate a common industrial policy in developing programs for the regional development and incentive-based incentive schemes. The experience of the advanced and developing countries has shown that a cluster approach serves as a basis for the rational and effective interaction of a particular sector, the state, research and higher educational institutions, in the innovative process.

Recognizing the need to increase economic potential, governments of developed and dynamically developing countries are investing heavily in RADW.

Thus, according to the ranking of the countries of the world on the level of expenditures on RADW/ Research and Development Expenditure, which is carried out by the United Nations Educational, Scientific and Cultural Organization UNESCO Institute for Statistics (2017), Israel spends $4.3 \%$ of GDP per annum, South Korea $4.2 \%$, Japan respectively $3.3 \%$, USA $-2.8 \%$, China 
$-2.1 \%$. At the same time as the Republic of Uzbekistan spends on these purposes the order of $0.1 \%$ of GDP. A sufficiently low level of financing of innovative activity in our country threatens to lag behind in the scientific and technical sphere and, as a consequence, in social and economic development. Such a situation is, first of all, caused by the lack of state scientific and technical policy, confirmed by practical action at all levels of legislative and executive authority. In addition, in Uzbekistan, until now, there has not been a competitive market for free capital, which has been interested in venture capital investments in small, innovative enterprises. We believe that for the development of the venture financing prevents undeveloped legal framework of the different aspects of the innovative sphere. Many developers badly present the entire process of the venture financing of the innovative activities from the initial stages to the implementation of the commercialization of its results in a market economy. This is due to the existing problems of the legal nature and taxation, as well as the lack of the required number of the experienced managers to manage new venture capital companies. Efforts to stimulate innovative activities should be focused on eliminating the main reasons for the lack of interest in the state and business in long-term, innovative projects.

\section{Conclusions and offers}

Based on the foregoing, among the most important issues that require the first development of the mechanisms for the state regulation of innovative activities in Uzbekistan, the following can be mentioned:

- Intensification of work to promote alternative forms of lending to large innovative projects (for example, SBIR (The Small Business Innovation Research program is a United States Government program and STTR (Small Business Technology Transfer).

- Development of a well-informed state scientific and technical policy for the perspective period until 2030, determination of strategic priorities for innovative development and their resource provision.

- A significant increase in government spending on research and development and bringing this indicator to 0.8 percent of GDP by 2021 .

- Creation of special institutions for financing innovative activities.

- Simplification of procedures and requirements for obtaining a bank loan to stimulate the innovative development of the country.

- Improving the microfinance system of the innovative development.

- Promoting private sector participation in identifying and financing research and technology development priorities.

- Creation of a constantly updated unified database of innovative projects and potential investors.

- Active implementation of the mechanism of RADW organization through the state order according to the program-target principle using project management mechanisms $[9,10]$.

- Creation of public use centers with unique scientific and technical equipment.

-Creation of a competitive hub for technology parks, free economic zones, free industrial zones, small industrial zones and research and production clusters for the development and implementation of advanced technologies [11].

- Simplification of procedures and increased transparency of the receipt and use of grants and technical assistance funds for innovative projects.

- Creation of a valid state system of protection of intellectual property rights and mechanisms for the prevention of the manufacture and sale of fake and counterfeit products. 
- Providing state guarantees for loans attracted to the innovation sphere. Inclusion of innovative tasks in the basic programs of economic and social development at the state and municipal levels.

- Development of state programs for the procurement of RADW results and science-intensive products carried out in innovative small enterprises.

- Development and certification of forecasting methods for evaluating the effectiveness of innovative programs and projects, taking into account the global experience of venture financing.

- Collaboration in the creation of effective centers of technical cooperation and the transfer of technology to small businesses at universities and research centers.

- Contributing to the development of private organizations in the field of expertise of innovative projects.

- Formation of a competitive market that stimulates the transition of the economy to an innovative development path and efficient use of resources.

- Development of corporate law and implementation of modern corporate governance principles taking into account international experience.

- Formation of a competitive market that stimulates the transition of the economy to an innovative development path and efficient use of resources.

- Improving antitrust policy, including through the introduction of public-private partnerships, ensuring non-discriminatory access to goods, works and services of natural monopolies for all legal entities and individuals, introducing effective pricing mechanisms for the products of monopolistic enterprises.

- Creating a level playing field for entrepreneurship and preventing monopolization of the domestic market

- Ensuring the complete digitalization of the conduct of the state cadaster by 2021 and simplifying the procedure for registering property [12].

- The activity of risky capital may increase only when sources of long-term financing, such as pension funds and insurance companies, become available. For the development of venture financing in Uzbekistan, in our opinion, the development and implementation of a number of the following state initiatives is required.

- Creation of a legal framework for the activities of venture capital funds, as well as for venture capital investments by pension funds, insurance companies and other credit and financial institutions;

- Introduction of world accounting standards and ensuring the transparency of the financial activities of enterprises in order to increase their attractiveness for investors;

- Development of an informational environment that allows small innovative enterprises and investors to find each other, as well as stimulate co-operative ties between small and large enterprises;

- Development of effective mechanisms of financial and fiscal stimulation of innovative activity;

- Development of measures to financially stimulate the activities of venture investors (tax breaks, state guarantees and investment insurance), investing in innovative and high-value small enterprises;

- Contributing to raising professionalism in the area of venture activity by training specialists in the corresponding business - schools and universities.

In conclusion, it should be noted that the creation of an effective national infrastructure to support innovation is one of the most important conditions for the further scientific, technical, and 
economic development of the Republic of Uzbekistan, and will also create truly favorable conditions for innovation in the context of the formation of a global digital economy.

\section{References:}

1. Kurpayanidi, K., Muminova, E., \& Paygamov, R. (2016). Management of innovative activity on industrial corporations. Lap Lambert Academic Publishing.

2. Wei, J., \& Liu, Y. (2015). Government support and firm innovation performance: Empirical analysis of 343 innovative enterprises in China. Chinese Management Studies, 9(1), 38-55. https://doi.org/10.1108/CMS-01-2015-0018

3. Rasulev, A. F., \& Trostyanskij, D. V. (2011). Razvitie innovacionnoj deyatel'nosti nacional'noj ekonomiki v postkrizisnyj period. Ekonomika i finansy (Uzbekistan), (1). 5-12. (in Russian)

4. Avramchikova, N. T., \& Volkov, D. O. (2018). Sovremennye metody ocenki effektivnosti gosudarstvennoj podderzhki innovacionnoj deyatel'nosti $\mathrm{v}$ regione. Regional'naya ekonomika: teoriya i praktika, $16(4$ (451)). 724-742. (in Russian) https://doi.org/10.24891/re.16.4.724

5. Suhina, Ju. V. (2017). Gosudarstvennoe upravlenie innovacionnym razvitiem predprinimatel'stva $\mathrm{v}$ regione [Governance innovative Development of Business in the Region]. Strategicheskie iniciativy social'no-jekonomicheskogo razvitija hozjajstvujushhih sub'ektov regiona v uslovijah vneshnih ogranichenij (pp. 311-314). (in Russian)

6. Volodin, V. M., Taktarova, S. V., \& Soldatova, S. S. (2018). Gosudarstvennaya Innovacionnaya politika, mekhanizmy regulirovaniya sfery innovacij $\mathrm{v}$ Rossii [State innovation policy, mechanisms of Regulation of the Sphere of innovations in Russia]. Izvestiya vysshih uchebnyh zavedenij. Povolzhskij region. Obshchestvennye nauki, (2 (46)). 154-163. https://doi.org/10.21685/2072-3016-2018-2-18 (in Russian)

7. Lyovkina, V. V. (2018). Mirovoj opyt finansirovaniya innovacionnoj deyatel'nosti sub"ektov ekonomiki [World experience of financing innovative Activity of the Subjects of the Economy]. Vestnik fakul'teta upravleniya SPbGEU, (3), 413-419. (in Russian)

8. 2019-2021-yillarda O‘zbekiston Respublikasini innovatsion rivojlantirish strategiyasini tasdiqlash to'g'risida. O'zbekiston Respublikasi Prezidentining Farmoni. 2018-yil 21-sentabr, PF5544-son. Qonun hujjatlari ma 'lumotlari milliy bazasi, 22.09.2018-y. http://lex.uz/docs/3913186 (in Uzbek)

9. Kurpayanidi, K. I., \& Abdullaev, A. M. (2018). Actual issues of the functioning of an innovative industrial enterprise. ISJ Theoretical \& Applied Science, 11(67), 74-81. https://dx.doi.org/10.15863/TAS.2018.11.67.14

10. Garcia, A., \& Mohnen, P. (2010). Impact of government support on R\&D and innovation.

11. Margianti, E. S., Ikramov, M. A., Abdullaev, A. M., Kurpayanidi, K. I., \& Ashurov, M. S. (2014). Systematical analysis of the position and further development of Uzbekistan national industry in the case of economic modernization. Monograph. Indonesia, Jakarta. Indonesia. Jakarta. Gunadarma Publisher.

12. Saastamoinen, J., Reijonen, H., \& Tammi, T. (2018). Should SMEs pursue public procurement to improve innovative performance? Technovation, (69), 2-14. https://doi.org/10.1016/j.technovation.2017.10.003

\section{Список литературы:}

1. Kurpayanidi K., Muminova E., Paygamov R. Management of innovative activity on industrial corporations/Lap Lambert Academic Publishing. 2016. 
2. Wei J., Liu Y. Government support and firm innovation performance: Empirical analysis of 343 innovative enterprises in China//Chinese Management Studies. 2015. V. 9. №1. P. 38-55. https://doi.org/10.1108/CMS-01-2015-0018

3. Расулев А. Ф., Тростянский Д. В. Развитие инновационной деятельности национальной экономики в посткризисный период // Экономика и финансы (Узбекистан). 2011. №1. С. 5-12.

4. Аврамчикова Н. Т., Волков Д. О. Современные методы оценки эффективности государственной поддержки инновационной деятельности в регионе // Региональная экономика: теория и практика. 2018. Т. 16. №4(451). С. 724-742. https://doi.Org/10.24891/re.16.4.724

5. Сухина Ю. В. Государственное управление инновационным развитием предпринимательства в регионе // Стратегические инициативы социально-экономического развития хозяйствующих субъектов региона в условиях внешних ограничений. 2017. С. 311 314.

6. Володин В. М., Тактарова С. В., Солдатова С. С. Государственная Инновационная политика, механизмы регулирования сферы инноваций в России // Известия высших учебных заведений. Поволжский регион. Общественные науки. 2018. №2(46). С. 154-163. https://doi.org/10.21685/2072-3016-2018-2-18

7. Лёвкина В. В. Мировой опыт финансирования инновационной деятельности субъектов экономики // Вестник факультета управления СПбГЭУ. 2018. №3. С. 413-419.

8. Об утверждении Стратегии инновационного развития Республики Узбекистан на 2019-2021 годы. Указ Президента Республики Узбекистан 21 сентября 2018 г, http://lex.uz/docs/3913186

9. Kurpayanidi K. I., Abdullaev A. M. Actual issues of the functioning of an innovative industrial enterprise // ISJ Theoretical \& Applied Science. 2018. V. 11. №67. P. 74-81. https://dx.doi.org/10.15863/TAS.2018.11.67.14

10. Garcia A., Mohnen P. Impact of government support on R\&D and innovation. 2010.

11. Margianti E. S. et al. Systematical analysis of the position and further development of Uzbekistan national industry in the case of economic modernization. Monograph. Indonesia, Jakarta // Indonesia. Jakarta. Gunadarma Publisher. 2014.

12. Saastamoinen J., Reijonen H., Tammi T. Should SMEs pursue public procurement to improve innovative performance? // Technovation. 2018. V. 69. P. 2-14. https://doi.org/10.1016/j.technovation.2017.10.003

Работа поступила

в редакцию 14.10 .2019 г.
Принята к публикациии 19.10.2019 2.

Ссылка для ц̧итирования:

Kurpayanidi K., Mamurov D. Features of the Support of the Innovative Activity: Foreign Experience and Practice for Uzbekistan // Бюллетень науки и практики. 2019. Т. 5. №11. С. 255261. https://doi.org/10.33619/2414-2948/48/29

Cite as (APA):

Kurpayanidi, K., \& Mamurov, D. (2019). Features of the Support of the Innovative Activity: Foreign Experience and Practice for Uzbekistan. Bulletin of Science and Practice, 5(11), 255-261. https://doi.org/10.33619/2414-2948/48/29 (in Russian). 